\title{
Evaluation of ESP textbooks: Evidence from ESP textbook of computer engineering major
}

Danaye Tous, Maryam

University of Guilan, Iran (maryam.dana@gmail.com)

Haghighi, Sara $\triangle$

University of Guilan, University Campus 2, International Campus, Iran (Sara.pardis@gmail.com)

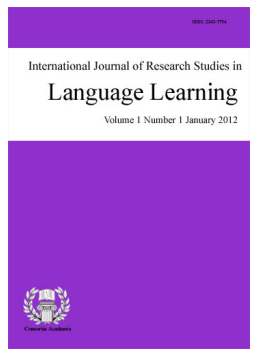

ISSN: 2243-7754 Online ISSN: 2243-7762

OPEN ACCESS

\section{Abstract}

The purpose of this study was to evaluate ESP textbook on "English for the students of computer engineering" taught at Payame Noor University in Astane (Guilan province, Iran). It was a mixed method research. The research instrument consisted of a researcher-made questionnaire which was designed on the basis of eight checklist references. Sample of this study consisted of 49 junior students majoring in computer engineering, who were selected through convenience sampling method. The textbook was evaluated in terms of six criteria of aims and approaches, design and organization, skills and strategies, topics, practical considerations and illustrations, language content and exercises. Data was collected through a five-point Likert scale questionnaire consisting of 22 items. Descriptive statistics including percentage, mean, and standard deviation were calculated for each item. Findings indicated that despite having pedagogical values, the textbook was not very good according to design and organization, language content and exercises, skills and strategies, practical considerations and illustrations. Finally, the pedagogical implication of findings for teaching grammatical items, listening materials, recycling and revision, writing activities and illustrations would be discussed.

Keywords: ESP; ESP materials; textbook; evaluation; checklist 


\section{Evaluation of ESP textbooks: Evidence from ESP textbook of computer engineering major}

\section{Introduction}

ESP is defined as the role of English in a language course of instruction in which the content and aims of the course are fixed by the specific needs of a particular group of learners (Richards \& Schmidt, 2010). Likewise, Silva (2002) states that English for Specific Purposes are a response to learners' needs and the acquisition of language relevant to their future jobs. As far as selecting ESP materials is concerned, Cunningsworth (1995) mentioned that careful selection should be made and the materials selected closely reflect the aims, methods and values of the teaching program and the needs of the learners. Vičič (2011) claims that ESP is predominantly student-centered, and consequently students' consideration should be at the top of the list of selection criteria. In addition, the level of language knowledge that the students have already acquired and the target level they will need to communicate successfully in their jobs should be taken into account.

Riazi (2003, p.52) believes that "textbooks play a very crucial role in the realm of language teaching and learning and they are considered the next important factors in the second/foreign language classroom after the teacher". McGrath (2002) argues that books are written to be relevant to as large a number of students as possible, which also means as wide a range of teaching-learning contexts as possible. According to him, no one book can be perfect for a particular institution, let alone a particular class within that institution or an individual within a class. Ellis (1997) believes that textbook evaluation helps teachers acquire useful, accurate, systematic, and contextual insights into the overall nature of textbook material, and it helps them move beyond impressionistic assessments. Textbook evaluation can be a particularly worthwhile means of conducting action research as well as a form of professional empowerment and improvement. Rubdy (2003) claims that a good evaluation framework helps match flexibility, adaptability, and relevance of a course book with learners and their changing needs. Evaluation is defined as "the process of worth or value of something, determining its merit" (Mertens, 2005, p.47).

A checklist is one of the common instruments to evaluate English Language Teaching (ELT) materials. It provides the researchers with a list of criteria of successful learning-teaching materials. With regard to these criteria, evaluators like researchers and students can evaluate the quality of the material (Soori, Kafipour, \& Soury, 2011). A large number of textbook evaluation framework researchers such as Byrd (2001), Harmer (2001), McDonough and Shaw (2003), and Tomlinson (2008) have used the checklist-based approach in helping teachers to evaluate ELT textbook (Litz, 2005). One major advantage of using the checklist approach is that it can provide a very economic and systematic way to ensure that all relevant items are considered for evaluation (McGrath, 2002). The current study takes into account the following items:

Aims and approaches - Celce-Murcia (2001) mentions that textbooks are for students, to meet their needs. Likewise, Cunnigsworth (1995) points out that course books should correspond to learners' needs and match the aims and objectives of the language learning program.

Design and organization - Breen and Candlin (1987) stated that the selection and organization of content in the materials is quite important. According to them, organization of the materials should be done in such a way that learners can work on them and internalize the content. Materials should be organized for simple and familiar 'things' to more complex and 'less familiar' ones. Sheldon (1988) also stated that the presence of structures and vocabularies moving gradually from simple to more complex should be taken into consideration. Additionally, Cunningsworth (1995) stated that by challenging students' intellect and engaging their interests, course books can provide much of the motivation which will stimulate them to become more independent in their use of English and in their learning. He claimed that this can be done by including interesting, stimulating topics and by 
encouraging learners to think for themselves around these topics and discuss them with others.

Language content and exercises - Regarding language content and exercises, Harding (2007) suggests that ESP teachers should use contexts, texts and situations from the students' subject area. Whether they are simulated or real, they will involve naturally the language that the students need. Further, he adds that they should exploit authentic materials that students use in their vocation or specialism - and don't be put off by this idea that it may not seem "normal English". According to him, ESP teachers should make the tasks authentic and get students doing things with the material that they actually need to do in their work. Additionally, Skierso (1991) suggests some criteria for the evaluation of exercises. He wonders whether there is a variety of activities in the textbook, and whether the instructions to the activities are appropriate for the level of students.

Skills and strategies - McDonough and Shaw (2003) stated that materials should enable the learners to see how the four skills (listening, speaking, reading, and writing) can be used effectively in appropriate contexts. According to them, as integrated skills materials are likely to involve learners in authentic and realistic tasks, their motivation level will increase. So, they perceive a clear rationale behind what they are being asked to do. Hyland (2005) states that specialist' samples, despite the fact that these samples are useful, may discourage students if the contents of these samples are too difficult (cited in McDonough, 2005). According to Belcher (2006), both tasks and authentic texts are advocated strongly in ESP material design.

Topics - Wilson and Yang (2007) believed that students should find the materials challenging, interesting and "usable" to call their attention and motivate them to learn through their interaction. Sheldon (1988) mentioned that there should be a link between materials, which means that the textbook should be organized in such a way that the exercises and units are connected based on situation, theme, topic, progression in grammar and lexis, and pattern of skill development. McDonough and Shaw (2003) claimed that textbook materials target a specific group and some topics are more suitable than others for any particular audience.

Practical considerations and illustrations - Clarity of layout and visuals such as tables, charts and diagrams are two important criteria for textbook evaluation (McDonough \& Shaw, 1993). Skierso (1991) stated that motivational attractiveness is one of the criteria for the evaluation of practical considerations and illustrations. McDonough and Shaw (2003) identified page presentation balance as a significant factor to book usability. Further, they added that there has been a tendency to use glossy prints in some materials to make the textbook appear more attractive.

\section{Literature review}

Many studies have evaluated the ESP textbooks according to engineering students' needs. Mehisto (2007) believed that in order to avoid the mismatch between the workplace needs and ESP courses offered, it is necessary to collaborate with content specialists and also to do needs analysis. In a study conducted by Othman (2005), students ranked speaking and writing as the most important skills. Likewise, Kwok (2004) recognized the need to develop oral and written communication skills. According to Romanowski and Sergey (2001), the lack of communication skills is reported to be the most prominent problem in engineering studies. Moreover, Riemer (2002) identified attributes for English proficiency of engineering students. According to him, the attributes consisted of: a) spoken language fluency, b) written language fluency, c) regional/national dialects, d) technical terminology, and e) professional jargon.

Although there are many researches concerning the evaluation of ESP textbooks for computer engineering students, few empirical studies, if any, have been conducted in Iran. Baleghizadeh and Rahimi (2011) mention that in Iranian context, the systematic evaluation of textbooks is not usually carried out and students' needs and opinions regarding the materials designed for them are ignored. Similarly, Eslami-Rasekh (2010) states that ESP textbooks designed for the students of engineering by the Ministry of Higher Education in Iran is not based on any systematic needs analysis. In a study conducted by Amirian and Tavakoli (2009), they evaluated the components of ESP textbooks for engineering students. They found that ESP courses have been successful in 
establishing background knowledge on terminology and reading proficiency of that specific field in the prospective engineers' minds. Atai (2008) in his evaluation on the academic language needs of computer science engineering students based on English for Specific Academic Purposes (ESAP) programs found that written skills and language components are important for learners. He reported that the students had some difficulties with skills of reading, writing, speaking, and listening.

A few studies have been conducted on the textbook evaluation. It seems that there is a shortage of study with respect to ESP textbook of computer engineering major. Thus, it remains a challenge to select an appropriate ESP textbook in this case. Since this is the first study that is focused on the ESP textbook of computer engineering major taught at Payame Noor Universities in Iran, the obtained results may be beneficial for the ESP teachers and material developers.

\subsection{Significance of the study}

In the field of computer engineering, there are many textbooks in the market places. The ESP teachers have to take into account the necessary factors involved in selecting appropriate textbooks. It seems that making a good choice is a challenge to the ESP teachers. Due to the policy in Payame Noor Universities in Iran, ESP teachers have to adapt Yoosef Khani, Ayat, and Farahi's book on English for the students of computer engineering. Therefore, the findings of this study can be beneficial for ESP teachers because they can make an informed choice. Moreover, the results of this study make them aware of students' perceptions. This may help them investigate if their views and students' views are matched. Further, material developers get benefit from these findings. This study may draw their attention to the importance of a well-designed textbook for computer engineering students in Payame Noor Universities.

\subsection{Research objectives and questions}

The purpose of this study was to investigate whether the ESP textbook of computer engineering taught at Payame Noor Universities conformed to the universal characteristics of EFL/ESL textbooks. To achieve this purpose, the present study sought to explore the following research questions:

1) Is ESP textbook of computer engineering major appropriate according to the aims and approaches?

2) Is ESP textbook of computer engineering major appropriate according to the design and organization?

3) Is ESP textbook of computer engineering major appropriate according to the skills and strategies?

4) Is ESP textbook of computer engineering major appropriate according to the topics?

5) Is ESP textbook of computer engineering major appropriate according to the language content and exercises?

6) Is ESP textbook of computer engineering major appropriate according to the practical considerations and illustrations?

\section{Methodology}

\subsection{Research design}

In order to achieve the purpose of this study, a mixed research with survey design and interview questions was used.

\subsection{Participants}

A total of 49 juniors of computer engineering (19 males and 30 females) from Payame Noor University 
(Astane Branch) participated in this study. Their age range was 20 to 22. They had ESP course at BA level. The participants were selected through convenience sampling method. In addition, two professors from Payame Noor Universities expressed their willingness to help us gain a better understanding of current textbook. They were interviewed by the researcher.

\subsection{Materials}

The material used for the purpose of the present study included: Yoosef Khani, Ayat, and Farahi's (2005) book on English for the students of computer engineering.

\subsection{Instruments}

Checklist - In order to examine the merits and drawbacks of the current textbook, eight checklists including checklists of Litz (2005), Garinger (2000), Sung Kyun Kwan University (2000), Littlejohn (1998), Ur (1996), Cunnigsworth (1995), Eskey and Grabe (1988), and Sheldon (1988) were browsed. Common features of these checklists were selected. The newly developed checklist was checked for its content validity by two university professors. The checklist was also adapted on the basis of the needs of the students. Six criteria of aims and approaches, design and organization, skills and strategies, topics, language content and exercises, practical considerations and illustrations were included in the checklist.

Questionnaire - A researcher-made questionnaire was used in this study. The questionnaire consisted of 22 items based on a five-point Likert scale ranging from excellent to very weak. Two university professors checked its content validity. The questionnaire was translated into Persian by the researchers. Then, the translated version was piloted with 15 students from the similar population. The Cronbach Alpha reliability was 0.79.

\subsection{Procedure}

At first, the researchers informed the participants about the study. The students were asked to scrutinize their ESP textbook against each of the criteria, including aims and approaches, design and organization, skills and strategies, topics, language content and exercises, practical considerations and illustrations. A week before conducting the survey, a pamphlet was distributed in ESP class by the researchers. All six criteria were explained in detail. Then, in order to clarify any ambiguity, the students were asked to contact the researchers through their email address. Soon after they were informed, the survey was distributed. During 45 minutes, each of the questions was explained to the students by one of the researchers. Then, they were requested to choose one of the options in terms of their ideas. Two weeks later, the researcher interviewed two professors concerning their perceptions of Yoosef Khani, Ayat, and Farahi's (2005) book on English for the students of computer engineering. They were asked two questions. The selected questions were developed by the researcher. All in all, the interview took less than 15 minutes. (See Appendix A for the transcribed interview questions)

\subsection{Data analysis}

In order to answer the six questions of this study, descriptive statistics was used. Then, the data were analyzed using SPSS version 20.

\section{Results}

Questionnaire - Two questions investigated aims and approaches: 1) To what extent do the aims of the course book correspond closely with needs of the learners? And 2) To what extent is the course book comprehensible?

Item one evaluated the extent of correspondence between the aims of course book and the learners' needs. Nearly half of the respondents (49\%) chose Average. That is, the aims of the course book were relevant to their 
needs to some extent. $31 \%$ of the respondents chose Good. This may suggest that less than one third of the respondents thought that the aims of the course book were relevant to their needs. Only $2 \%$ of the respondents supported the statement that "the aims of the course book correspond closely with the needs of the learners to high extent". That is, they chose Excellent. On the contrary, $12 \%$ of the respondents chose Weak and $6 \%$ of the respondents chose Very weak. It can be noted that the aims of the course book partially met the needs of these learners. With regard to the second item, respondents' ratings were not completely positive. $12 \%$ of the respondents chose Excellent and $12 \%$ of the respondents chose Good. $47 \%$ of the respondents believed that the course book was not comprehensible enough. That is, they chose Average. On the contrary, 24\% of the respondents chose Weak and 5\% of the respondents chose Very weak. In other words, less than one third of the respondents were against the claim of "the course book is comprehensible to high extent".

\section{Table 1}

Descriptive statistics for aims and approaches

\begin{tabular}{ccccc}
\hline Item No & Minimum & Maximum & Mean & Std. Deviation \\
\hline 1 & 1.00 & 5.00 & 2.89 & 0.87 \\
2 & 1.00 & 5.00 & 3.55 & 4.27 \\
\hline Note. $1=$ Excellent, 2=Good, 3=Average, 4=Weak, 5=Very Weak
\end{tabular}

Three questions investigated design and organization: 3) To what extent is the content sequenced on the basis of complexity? 4) To what extent is there adequate recycling and revision? And 5) To what extent are the materials suitable for individual study?

Item three was concerned with the level of difficulty. While nearly half of the respondents (47\%) thought that the content of the textbook was well-sequenced on the basis of complexity, by choosing Good, more than one third of the respondents (39\%) chose Average and $14 \%$ of the respondents chose Weak. No one chose Excellent and Very weak. Recycling and revision were evaluated in item four. More than half of the respondents (53\%) didn't think that recycling and revision was adequate to high extent. They chose Very weak. Similarly, more than one third of the respondents $(41 \%)$ chose Weak. On the other hand, only $2 \%$ of the respondents favored the claim of "recycling and revision is adequate". That is, they chose Good. $4 \%$ of the respondents chose Average. They might think that recycling and revision were adequate to some extent. Item five aimed at finding out whether the materials are suitable for individual study or not. While less than one third of the respondents supported the claim that "the materials are suitable for individual study", nearly half of the respondents argued against the statement that "the materials are suitable for individual study". That is, $13 \%$ chose Excellent, $15 \%$ chose Good, $18 \%$ chose Weak, and $22 \%$ chose Very weak. Only one third of the respondents (32\%) chose Average.

Table 2

Descriptive statistics for design and organization

\begin{tabular}{ccccc}
\hline Item No & Minimum & Maximum & Mean & Std. Deviation \\
\hline 3 & 2.00 & 4.00 & 2.69 & 0.71 \\
4 & 2.00 & 5.00 & 4.42 & 0.70 \\
5 & 1.00 & 5.00 & 3.26 & 1.36 \\
\hline
\end{tabular}

Note. $1=$ Excellent, $2=$ Good, 3=Average, $4=$ Weak, 5=Very Weak

Two questions investigated language content and exercises: 6) To what extent does the course book cover the main grammar items appropriate to your level? And 7) To what extent is the language style such as computerese matched to social situation? Regarding item six, the majority of the respondents (78\%) chose Very weak, $14 \%$ chose Weak, and $6 \%$ chose Average. Only $2 \%$ of the respondents had positive attitudes towards the appropriate coverage of the main grammar in terms of students' level. That is, they chose Good. No one chose Excellent. In reply to item seven, almost half of the respondents thought that language style was matched to social situation to some extent. That is, $49 \%$ of the respondents chose Average. More than one third of the 
respondents believed that language styles were not appropriately matched to social situation. That is, $29 \%$ of the respondents chose Weak and $9 \%$ of them chose Very weak. $20 \%$ of the respondents supported the claim that "language style is very well-matched to the social situation". That is, they chose Good.

Table 3

Descriptive statistics for language content and exercises

\begin{tabular}{ccccc}
\hline Item No & Minimum & Maximum & Mean & Std. Deviation \\
\hline 6 & 2.00 & 5.00 & 3.22 & 0.89 \\
7 & 2.00 & 5.00 & 3.95 & 0.91 \\
\hline
\end{tabular}

Note. $1=$ Excellent, $2=$ Good, $3=$ Average, 4=Weak, 5=Very Weak

Nine questions investigated skills and strategies: 8) To what extent are all four skills adequately covered? 9) To what extent are reading passages and associated activities suitable for students' levels? 10) To what extent are listening materials interesting? 11) To what extent is listening material as authentic as possible? 12) To what extent is listening material accompanied by background knowledge information? 13) To what extent is listening material accompanied by activities and questions? 14) To what extent is material for spoken English well-designed to equip learners for real-life interaction? 15) To what extent are writing activities suitable in terms of amount of guidance/control? And 16) To what extent are writing activities suitable in terms of appropriate style such as punctuation, spelling, etc.?

With regard to the four skills, more than two third of the respondents were unsatisfied with adequate coverage of all four skills in their textbook. That is, they chose Weak (41\%) and Very weak (33\%). On the contrary, only $6 \%$ of the respondents felt that all four skills were provided adequately. That is, they chose Good. $20 \%$ of the respondents chose Average and no one chose Excellent. Item nine attempted to evaluate suitability of reading passages and associated activities for students' levels. This item received a parallel rating. In reply to this item, almost one third of the respondents had positive view and one third of the respondents had negative view. That is, $8 \%$ chose Excellent, $24 \%$ chose Good, $27 \%$ chose Weak, and $6 \%$ chose Very weak. More than one third of the respondents $(35 \%)$ believed that reading passages and associated activities were suitable for students' levels to some extent. That is, they chose Average.

Item ten was concerned with listening materials. On the one hand, $24 \%$ of the respondents thought that listening materials were interesting. That is, they chose Good. On the other hand, $24 \%$ of the respondents believed that listening materials were not interesting enough. That is, they chose Weak. Only $9 \%$ of the respondents felt that listening materials were interesting to high extent. On the contrary, $14 \%$ of the respondents took an opposite view. They chose Very weak. With regard to the extent of authenticity in listening materials, only $4 \%$ chose Excellent and $29 \%$ chose Good whereas, less than one third of the respondents thought that listening materials didn't contain real-life issues to high extent. That is, they chose Weak (14\%) and Very weak $(6 \%)$. Additionally, nearly half of the respondents (47\%) believed that listening materials were authentic to some extent. That is, they chose Average. Item twelve referred to the extent of background knowledge information in listening materials. 12\% chose Excellent and 10\% chose Good. 29\% of the respondents chose Average. $41 \%$ chose Weak and $8 \%$ chose Very weak alternatives. It is understood that nearly half of the respondents believed that the materials for listening were not accompanied appropriately by background knowledge which helped comprehension. Only less than one third of the respondents were in favor of the idea that listening materials were accompanied by background knowledge to high extent. In response to item thirteen, the ideas of the respondents were almost equally divided. While one third of the respondents thought that listening materials were accompanied by activities and questions, slightly more than one third of the respondents disagreed. That is, $13 \%$ chose Excellent, 20\% chose Good, 12\% chose Weak, and 22\% chose Very weak. Also, 33\% of the respondents chose Average. In other words, they believed that listening materials were accompanied by activities and questions to some extent.

Item fourteen was concerned with materials for spoken English. Most of the respondents were in favor of 
Danaye Tous, M. \& Haghighi, S.

the idea that the materials for spoken English were not well-designed in order to equip learners for real-life interaction. That is, 35\% chose Weak, 31\% chose Very weak, 18\% chose Average, 14\% chose Good, and 2\% chose Excellent, respectively. Item fifteen was concerned with writing activities. The majority of the respondents might favor the statement "the textbook lacks writing activities such as guided and controlled" or "writing activities are not appropriately designed in terms of amount of guidance and control". They chose Very weak $(61 \%)$ and weak (33\%), respectively. Only 6\% of the respondents chose Average and no one chose Good and Excellent alternatives. In item sixteen, writing activities were evaluated according to the use of appropriate style such as punctuation, spelling, etc. Respondents' ratings were quite negative. That is, none of the respondents had positive attitude towards the use of appropriate style in writing activities. 51\% chose Very weak and $41 \%$ chose Weak, respectively. Only $8 \%$ of the respondents felt that writing activities were suitable in terms of use of appropriate style to some extent. They chose Average.

Table 4

Descriptive statistics for skills and strategies

\begin{tabular}{ccccc}
\hline Item No & Minimum & Maximum & Mean & Std. Deviation \\
\hline 8 & 2.00 & 5.00 & 3.95 & 0.91 \\
9 & 1.00 & 5.00 & 3.02 & 1.03 \\
10 & 1.00 & 5.00 & 3.08 & 1.15 \\
11 & 1.00 & 5.00 & 3.24 & 1.18 \\
12 & 1.00 & 5.00 & 2.87 & 0.85 \\
13 & 1.00 & 5.00 & 3.16 & 1.34 \\
14 & 1.00 & 5.00 & 3.75 & 1.10 \\
15 & 3.00 & 5.00 & 4.55 & 0.61 \\
16 & 2.00 & 5.00 & 4.30 & 0.79 \\
\hline
\end{tabular}

Note. 1=Excellent, 2=Good, 3=Average, 4=Weak, 5=Very Weak

Three statements investigated topics: 17) To what extent is there variety and range of topic? 18) To what extent will the topics help expand students' awareness and enrich their experience? And 19) To what extent has the ordering of material by topics been arranged in a logical fashion? Regarding item seventeen, more than half of the respondents (53\%) who chose Good and $8 \%$ of them who chose Excellent thought that there was sufficient variety in the topics of textbook. On the other hand, only $6 \%$ of the respondents chose Weak and $2 \%$ chose Very weak alternatives, respectively. Slightly less than one third of the respondents (31\%) chose Average. With regard to item eighteen, $27 \%$ of the respondents chose Average and less than one third of the respondents chose Weak and Very weak. On the contrary, nearly half of the respondents (45\%) chose Good. Only $2 \%$ of them who chose Excellent believed that the topics incorporated in the textbook help them expand their awareness and enrich their experience to high extent. Item nineteen attempted to evaluate the ordering of material by topics. More than half of the respondents (55\%) thought that the topics were arranged in a logical fashion to some extent. They chose Average. Only a few respondents (4\%) chose Very weak. Similarly, $12 \%$ of them chose Weak. Slightly less than one third of the respondents $(29 \%)$ chose Good. No one believed that the ordering of material by topics was in a logical fashion to high extent. That is, none of the respondents chose Excellent.

Table 5

Descriptive statistics for topics

\begin{tabular}{ccccc}
\hline Item No & Minimum & Maximum & Mean & Std. Deviation \\
\hline 17 & 1.00 & 5.00 & 2.44 & 0.86 \\
18 & 1.00 & 5.00 & 3.06 & 0.98 \\
19 & 2.00 & 5.00 & 2.93 & 0.77 \\
\hline
\end{tabular}

Note. 1=Excellent, 2=Good, 3=Average, 4=Weak, 5=Very Weak

Three questions investigated practical considerations and illustrations: 20) To what extent is the book easy to obtain? 21) To what extent is the book attractive in appearance? And 22) To what extent do the graphic illustrations motivate learners to talk about the subject? In response to item twenty, the findings showed that the majority of the respondents couldn't find the book easily. That is, 50\% chose Weak, 34\% chose Very weak, and 
$8 \%$ chose Average. On the other hand, only a few respondents obtained their textbook with no difficulty. In other words, $2 \%$ of the respondents chose Excellent and $6 \%$ of them chose Good. Item twenty one referred to the appearance of textbook. 55\% chose Very weak and 35\% chose Weak. Therefore, it is understood that the majority of the respondents' ratings were negative overall. Only 2\% chose Good and 3\% chose Average. Item twenty two was concerned with the graphic illustrations. None of the respondents chose Excellent. Most of the respondents had negative view. That is, $22 \%$ of the respondents chose Average, $8 \%$ of them chose Good, 20\% chose Weak, and $50 \%$ chose Vey weak.

Table 6

Descriptive statistics for practical considerations and illustrations

\begin{tabular}{ccccc}
\hline Item No & Minimum & Maximum & Mean & Std. Deviation \\
\hline 20 & 1.00 & 5.00 & 4.10 & 0.96 \\
21 & 2.00 & 5.00 & 4.40 & 0.78 \\
22 & 2.00 & 5.00 & 4.10 & 1.02 \\
\hline
\end{tabular}

Note. $1=$ Excellent, $2=$ Good, $3=$ Average, $4=$ Weak, $5=$ Very Weak

Interview - To achieve the reliability of the findings, two professors were interviewed. They were asked some general questions about the strengths and weaknesses of the related ESP textbook, and also their views on aims and approaches, design and organization, skills and strategies, topics, practical considerations and illustrations, language content and exercises of the textbook. Actually, question one provided professors with an opportunity to state their attitudes towards the ESP textbook. They frequently mentioned the weaknesses like lack of appropriate illustrations and adequate revision. They had a few suggestions like use of graphs and tables. In question two, they agreed that the ESP textbook did not meet the six criteria appropriately. For instance; they thought that majority of students had difficulty in dealing with four skills. One of the professors stated "many students have poor reading comprehension skill". Another professor stated "several students are not motivated enough because the ESP textbook provided them with mechanical exercises". He was in favor of the idea that textbook's effective use of authentic materials could engage students in meaningful tasks. In all, the results from interviews indicated that the two professors found using the present ESP textbook somewhat inappropriate.

Table 7

Student textbook evaluation

\begin{tabular}{cccccc}
\hline Item No & Excellent & Good & Average & Weak & Very Weak \\
\hline 1 & $2 \%$ & $31 \%$ & $49 \%$ & $12 \%$ & $6 \%$ \\
2 & $12 \%$ & $12 \%$ & $47 \%$ & $24 \%$ & $5 \%$ \\
3 & - & $47 \%$ & $39 \%$ & $14 \%$ & 5 \\
4 & - & $2 \%$ & $4 \%$ & $41 \%$ & $53 \%$ \\
5 & $13 \%$ & $15 \%$ & $32 \%$ & $18 \%$ & $22 \%$ \\
6 & - & $2 \%$ & $6 \%$ & $14 \%$ & $78 \%$ \\
7 & - & $20 \%$ & $49 \%$ & $29 \%$ & $9 \%$ \\
8 & - & $6 \%$ & $20 \%$ & $41 \%$ & $33 \%$ \\
9 & $8 \%$ & $24 \%$ & $35 \%$ & $27 \%$ & $6 \%$ \\
10 & $9 \%$ & $24 \%$ & $29 \%$ & $24 \%$ & $14 \%$ \\
11 & $12 \%$ & $10 \%$ & $29 \%$ & $41 \%$ & $8 \%$ \\
12 & $4 \%$ & $29 \%$ & $47 \%$ & $14 \%$ & $6 \%$ \\
13 & $13 \%$ & $20 \%$ & $33 \%$ & $12 \%$ & $22 \%$ \\
14 & $2 \%$ & $14 \%$ & $18 \%$ & $35 \%$ & $31 \%$ \\
15 & - & - & $6 \%$ & $33 \%$ & $61 \%$ \\
16 & - & $8 \%$ & $41 \%$ & $51 \%$ \\
17 & $8 \%$ & $53 \%$ & $31 \%$ & $6 \%$ & $2 \%$ \\
18 & $2 \%$ & $45 \%$ & $27 \%$ & $18 \%$ & $8 \%$ \\
19 & - & $29 \%$ & $55 \%$ & $12 \%$ & $4 \%$ \\
20 & $2 \%$ & $6 \%$ & $8 \%$ & $50 \%$ & $34 \%$ \\
21 & - & $2 \%$ & $3 \%$ & $35 \%$ & $55 \%$ \\
22 & - & $8 \%$ & $22 \%$ & $20 \%$ & $50 \%$ \\
\hline
\end{tabular}




\section{Discussion}

\subsection{Strengths}

The first research question, "Is ESP textbook of computer engineering major appropriate according to the aims and approaches?" was measured through two items. Results indicated that the aims of the textbook were in harmony with the needs of learners. As it is stated, the textbooks should meet the students' needs (Celce-Murcia, 2001). With regard to item two, the results showed that only less than one third of the students had negative view. In contrast, most of the respondents had fairly positive view. That is, the textbook provided some examples to support the activities. In addition, the textbook didn't lack supplementary materials. The second research question, "Is ESP textbook of computer engineering major appropriate according to the design and organization?" was measured through three items. The findings revealed that the textbook satisfied nearly most of the students with regard to the sequencing of content on the basis of complexity. Appropriateness of content in terms of complexity is an important criterion in the process of textbook evaluation. This factor is mostly stated by Breen and Candlin (1987), and Sheldon (1988). Additionally, determining the suitability of topics was one of the objectives of the present study. The fourth research question, "Is ESP textbook of computer engineering major appropriate according to the topics?" was measured through three items. The results revealed that the textbook covered varieties of topics to enhance learning process and to meet the needs of the computer engineering students. It is assumed that including various topics appealed to maintain the students' interest. According to Cunnigsworth (1995), interesting topics will motivate learners. Also, topics were graded throughout the textbook in such a way that helped learners take responsibility for future job. As a matter of fact, raising awareness and enriching learners' experience is quite important. It seems that authors of the current textbook checked whether or not the textbook helped expand students' awareness and enriched their experience.

\subsection{Weaknesses}

The second research question "Is ESP textbook of computer engineering major appropriate according to the design and organization?" was measured through three items. The results of item four revealed that the current textbook was not very effective on the basis of adequate recycling and revision. The findings implied that recycling and revision was absent in the textbook to high extent. It is worth noting that lack of recycling and revision may encounter leaners with some difficulties because what has been learned is reinforced and internalized by appropriate recycling. Further, item five evaluated the suitability of materials for individual study. The importance of fostering individual study should not be overlooked. Encouraging learners to develop their own learning strategies and to become independent learners is identified as one of the aspects in Ur's (1996) checklist. According to Larsen -Freeman (2000, p.53), "the teachers should help learners take responsibility for their own learning".

The third research question, "Is ESP textbook of computer engineering major appropriate according to the skills and strategies?" was measured through nine items. The results showed that students have found the textbook inappropriate in terms of four skills coverage. It seems that the textbook did not cover all four language skills. Cunnigsworth (1995) suggested that the course book should deal with all four skills. Regarding the reading skill, item nine addressed the students' judgments of suitability of reading passages and associated activities for their level. The results showed that the proportion of positive and negative attitudes of the students towards reading passages were almost the same. That is, there was no agreement regarding the reading skill. This may suggest that the textbook didn't gain the support of the whole class, however; reading comprehension is the basic part of all ESP courses in Iran (cited in Rajabi \& Azarpour, 2011). These results contradicted that of Amirian and Tavakoli (2009) who claimed that ESP courses have been successful in reading instruction in the prospective engineers' minds. With regard to item ten, it seems that listening materials didn't meet students' interests. As mentioned in this study, interesting materials motivate learners. The results showed that designing 
interesting listening materials was ignored by the material developers. Furthermore, much more attention should be given to authenticity in listening instructional materials. Using authentic listening task which is relevant to the computer engineering students' needs enhances their achievements in the real world.

The results also revealed that almost half of the learners had a great difficulty in comprehending the listening texts. One of the main reasons might be due to the fact that students' background knowledge was not activated. According to Nunan (2007), comprehension relies on listeners' successful activation of their prior knowledge. Otherwise, the students would fail to comprehend listening materials. Moreover, other important factors should be taken into consideration like sound quality, level of the leaners, and the range of unknown vocabularies. Item fourteen dealt with speaking skill. The results revealed that the current textbook insufficiently focused on this skill. According to Othman (2005), speaking skill is one of the most needed skills by the engineering students. So, developing speaking skill is essential for students majoring in engineering because the materials for spoken English should equip learners for real-life interaction like participating in seminars, listening to lectures, etc. Regarding item fifteen, the results for the writing skill revealed that more than half of the learners responded negatively. It seems that writing activities were not suitable in terms of amount of guidance/control and the use of appropriate style such as punctuation, spelling, etc. Due to these shortcomings, it may be inferred that students were likely to find writing essays difficult to cope with. Also, this drawback may decrease students' desire to write more. All in all, the results of the four skills were consistent with the findings of Atai (2008). He claimed that students had some difficulties with listening, speaking, reading, and writing. The fifth research question, "Is ESP textbook of computer engineering major appropriate according to the language content and exercises?" was measured through two items. It was revealed that the majority of learners might have thought that the grammar items were difficult for them to cope with. Clearly, grammar is required by the computer engineering students in order to communicate correctly. So, it is necessary to check whether the grammar items in the textbook are suitable for the level of the learners.

The sixth research question, "Is ESP textbook of computer engineering major appropriate according to the practical considerations and illustrations?" was measured through items 20, 21, and 22. The results revealed that the currently used ESP textbook was not easy to obtain. A large number of the students couldn't find it easily. Additionally, as far as the appearance of textbook was concerned, the students were not satisfied with. It seems that the textbook was not designed attractively. Regarding appropriate illustrations, more than half of the learners didn't find this textbook interesting on the basis of its graphic illustrations. As mentioned by Sheldon (1988), graphic illustrations regarded as necessary factors for a successful textbook. Furthermore, an appropriate illustration is a criterion that motivates learners (Skierso, 1991) but such an important aspect has been neglected in this textbook.

\section{Conclusion}

Evaluation of the ESP textbook of computer engineering taught at Payame Noor Universities gave us a clear understanding of its aims, organizations, skills, topics, exercises, and illustrations. The results showed that the ESP textbook meet the students' needs. The general consensus among students is that the textbook provides some examples to support the activities. Additionally, the sequencing of content on the basis of complexity and the suitability of topics are not different from what computer engineering students expected. Contrary to these strengths, the students' responses on the questionnaire items imply the need for paying attention to weaknesses. While internalizing the content through appropriate organizations of materials is recommended in the literature, the current textbook is not very effective in terms of adequate recycling and revision. Besides, encouraging students to become independent learners has been overlooked. Also, all four language skills are not covered adequately. The textbook fails to provide students with appropriate illustrations, as well. In conclusion, it seems that the current textbook does not meet the engineering students' expectations to high extent. However, it should be mentioned that "there is no perfect textbook which meets all the requirements of teachers and students" (Cunningsworth, 1984 p. 4). 


\subsection{Limitations and delimitations of the study}

This study was limited to a group of 49 college students. It lacked random sampling method. The first delimitation was that this study was concerned with assessing junior college students' perceptions. In addition, this study did not include college students who attend the public universities. Thus, the results cannot be generalized to public college students in Iran.

\subsection{Pedagogical implications}

The findings of the present study hold important implications for material developers and teachers. First of all, some points should be taken into consideration by material developers while revising the current textbook: 1) ensuring the revision sections in the next edition of the textbook, 2) fostering individual learning, 3) covering all four skills adequately to meet the needs of students, 4) giving more priority to reading passages and associative activities, 5) reconsidering the lack of emphasis on interesting listening materials, 6) emphasizing on authentic listening materials,7) providing materials that facilitate real-life interaction, 8) providing the textbook with writing activities suitable in terms of amount of guidance/control, 9) modifying grammar items matched with the students' level, 10) providing graphic illustrations that aim to motivate learners to talk about the subjects, and 11) focusing much more attention on attractive appearance. Moreover, the findings of this study enable the ESP teachers to adapt the computer engineering textbook more relevant to the students' needs. Evaluation checklist used in this study helps the ESP teachers gain a deeper insight in selecting the appropriate textbook.

\subsection{Recommendations for further research}

Future studies may explore several teachers' views to see whether they support the claim that the ESP textbook of computer engineering taught at Payame Noor Universities conforms to the universal characteristics of EFL/ESL textbooks. In addition, future studies may investigate the evaluation of ESP textbook, utilizing random sampling method with the larger sample sizes. Future researchers need to spend a longer time than the time spent in this study. In fact, the time constraint hampered this study to investigate more than two professors' views for gathering data.

\section{References}

Amirian, Z., \& Tavakoli, M. (2009). Reassessing ESP courses offered to engineering studies in Iran, English for Specific Purposes World, 8(23), 1-13.

Atai, M. R. (2008). Revisiting the status of CALL and ESAP in Iran: Potentials and obstacles. Paper presented at XVII Symposium on languages for specific purposes: Methods and aims, University of Aarhus, Denmark.

Baleghizadeh, S., \& Rahimi, A. H. (2011). Evaluation of an ESP textbook for the students of sociology. Journal of Language Teaching and Research, 2(5), 1009-1014. http://dx.doi.org/10.4304/jltr.2.5.1009-1014

Belcher, D. D. (2006). English for specific purposes: Teaching to perceived needs and imagined futures in worlds of works, study, and everyday life. TESOL Quarterly, 40(1), 134-156. http://dx.doi.org/10.2307/40264514

Breen, M. P., \& Candlin, C. N. (1987). Which materials? A consumer's and designer's guide. In L.E. Sheldon (Ed.), Problem in Evaluation and Development (pp. 13 -28).Oxford: Modern English Publications.

Celce-Murcia, M. (2001). Teaching English as a second or foreign language ( $\left.3^{\text {rd }} \mathrm{ed}\right)$. Boston: Heinle \& Heinle.

Cunningsworth, A. (1995). Choosing your course book. Oxford: Heinemann.

Cunningsworth, A. (1984). Evaluating and selecting EFL teaching materials. London: Heinemann.

Ellis, R. (1997). The empirical evaluation of language teaching materials. English Language Teaching, 51(1), 36-42. http://dx.doi.org/10.1093/elt/51.1.36

Eslami-Rasekh, Z. R. (2010). Teachers voice vs. students voice: A needs analysis approach to English for academic purposes (EAP) in Iran. English Language Teaching, 3(1), 2-11. 
Harding, K. (2007). English for specific purposes. Oxford: Oxford University Press.

Kwok, M. (2004). Disciplinary differences in the development of employability skills of recent university graduates in Manitoba: Some initial findings. Higher Education Perspectives, 1(1), 60-77.

Larsen-Freeman, D. (2000). Techniques and principles in language leaching (2 $\left.{ }^{\text {nd }} \mathrm{ed}\right)$. Oxford University Press, Oxford, UK.

Litz, D. R. A. (2005). Text book evaluation and ELT management: A South Korean case study. Retrieved April 6, 2013, from http://www.asian-Efl-journal.com/Litz-thesis.pdf

McDonough, J. (2005). Perspectives on EAP: An interview with Ken Hyland. English Language Teaching, 59, 57-64. http://dx.doi.org/10.1093/elt/cci008

McDonough, J. \& Shaw, C. (2003). Materials and methods in ELT: A teacher's guide (2 ${ }^{\text {nd }}$ ed). Blackwell Publishing Ltd.

McDonough, J., \& Shaw, C. (1993). Materials and methods in ELT. Oxford: Blackwell.

McGrath, I. (2002). Materials evaluation and design for language teaching. Edinburgh: Edinburgh University Press.

Mehisto, P. (2007). What a school needs to consider before launching a CLIL program: The Estonian experience. In D. Marsh \& D. Wolff (Eds.), Diverse contexts - Converging goals. CLIL in Europe (pp.61-77). Frankfurt and Main: Peter Lang.

Mertens, M. (2005). Research and evaluation in education and psychology ( $2^{\text {nd }}$ ed). California: Sage Publication Inc.

Nunan, D. (2007). Listening in language learning. Sino-US English Teaching, 1(6), 32-33.

Othman, J. (2005). English language use among EFL learners in Sunway University College. Sunway Academic Journal, 8(23), 93-100.

Rajabi, P., \& Azarpour, N. (2011). Academic needs of Iranian business administration students in ESP classed. Contemporary Online Language Education Journal, 1, 20-32.

Riazi, A. M. (2003). What textbook evaluation schemes tell us? A study of the textbook evaluation schemes of three decades. In W. A. Renandya. (Ed.), Methodology and materials design in language teaching (pp.52-68). Singapore: SEAMEO Regional Center.

Richards J. C., \& Schmidt, R. (2010). Longman dictionary of language teaching and applied Linguistics ( $\left.4^{\text {th }} \mathrm{ed}\right)$. Harlow: Pearson Education Ltd.

Riemer, M. J. (2002). English and communication skills for the global engineer: Global Journal of Engineering Education, 6(1), 91-100.

Romanowski, C. J., \& Sergey, P. (2001). A message from recent engineering graduates in the workplace: Results of a survey on technical communication skills, Journal of Engineering Education, 90(4), 685-693. http://dx.doi.org/10.1002/j.2168-9830.2001.tb00660.x

Rubdy, R. (2003). Selection of materials. In Tomlinson, B. (Ed.), Developing materials for language teaching (pp. 37-57). London: Continuum.

Sheldon, L. (1988). Evaluation of ELT text books and materials. English Language Teaching, 42(4), 237-246. http://dx.doi.org/10.1093/elt/42.4.237

Silva, F. (2002). ESP teaching for Learners in the Health Sciences Field, American Journal of Nursing, 1, 35-40.

Skierso, A. (1991). Text book selection and evaluation. In Celce-Murcia (Ed.), Teaching English as a Second or Foreign Language (pp. 432-453). Boston: Heinle \& Heinle Publishers.

Soori, A., Kafipour, R., \& Soury, M. (2011). EFL textbook evaluation and graphic representation. European Journal of Social Sciences, 26(3), 481-493.

Vičič, P. (2011). Preparing materials for ESP teaching. Retrieved March 5, 2012, from http://www.sdutsj.edus.si/InterAlia

Wilson, K., \& Yang, L. (2007). A social constructivist approach to teaching reading: turning the rhetoric into reality. China English Language Education Association Journal, 30(1), 51-56.

Yoosef Khani, M., Ayat, N., \& Farahi, A. (2005). English for the students of computer engineering. Tehran: Payame Noor University Publication. 


\section{Appendix A. Professors Interview}

Interviewer: I appreciate your willingness. Our purpose is to provide a better ESP textbook at Payame Noor Universities. Please answer the questions. Our conversation will be taped.

$>\quad$ Would you please describe the students' textbook concerning aims and approaches?

$>$ Would you please describe the students' textbook concerning design and organization?

$>\quad$ Would you please describe the students' textbook concerning skills and strategies?

$>\quad$ Would you please describe the students' textbook concerning topics?

$>$ Would you please describe the students' textbook concerning practical considerations and illustrations?

$>\quad$ Would you please describe the students' textbook concerning language content and exercises?

$>\quad$ What are some strengths and weaknesses of the present ESP textbook?

\section{Appendix B. Questionnaire}

Student textbook evaluation

\begin{tabular}{l} 
Item No Excellent Good Werage Weak \\
\hline To what extent are the aims of the course book corresponded closely with needs of the learners? \\
To what extent is the course book comprehensible? \\
To what extent is the content sequenced on the basis of complexity? \\
To what extent is there adequate recycling and revision? \\
To what extent are the materials suitable for individual study? \\
To what extent does the course book cover the main grammar items appropriate to your level? \\
To what extent is the language style such as computerese matched to the social situation? \\
To what extent are all four skills adequately covered? \\
To what extent are reading passages and associated activities suitable for students' levels? \\
To what extent are listening materials interesting? \\
To what extent is listening material as authentic as possible? \\
To what extent is listening material accompanied by background knowledge information? \\
To what extent is listening material accompanied by activities and questions? \\
To what extent is material for spoken English well-designed to equip learners for real-life interaction? \\
To what extent are writing activities suitable in terms of amount of guidance/control? \\
To what extent are writing activities suitable in terms of use of appropriate style such as punctuation, spelling, \\
etc.? \\
To what extent is there variety and range of topic? \\
To what extent will the topics help expand students' awareness and enrich their experience? \\
To what extent has the ordering of material by topics been arranged in a logical fashion? \\
To what extent is the book easy to obtain? \\
To what extent is the book attractive in appearance? \\
To what extent do the graphic illustrations motivate learners to talk about the subject? \\
\hline
\end{tabular}

